\title{
Erratum to correlation among VEGFR3 gene promoter methylation, protein overexpression, and clinical pathology in early gastric cancer
}

\author{
Xiu-Feng Li ${ }^{1,2}$, Ting-Guo Zhang ${ }^{2,3}$, Yun-Xiang Zhang ${ }^{1}$ \\ ${ }^{1}$ Department of Pathology, Wei Fang People's Hospital, Weifang 261041, China; ${ }^{2}$ Shandong University School of Medicine of China, Jinan \\ 250012, China; ${ }^{3}$ Department of Pathology, Qilu Hospital, Shandong University, Jinan 250012, China \\ Correspondence to: Ting-Guo Zhang. School of Medicine, Shandong University, Li Xia, Jinan 250012, China; Department of Pathology, Qilu \\ Hospital, Shandong University, Li Xia, Jinan, 107 West Wenhua Road, Jinan 250012, China. Email: ztguo@sdu.edu.cn; lixiufeng.82@163.com.
}

doi: $10.21037 /$ tcr-2020-006

View this article at: http://dx.doi.org/10.21037/tcr-2020-006

Erratum to: Transl Cancer Res 2020;9:3499-506.

Correlation among VEGFR3 gene promoter methylation, protein overexpression, and clinical pathology in early gastric cancer

In the article that appeared on Page 3499-3506, Vol 9, No 5 (May 2020) Issue of the journal Translational Cancer Research (1), there is an error on the affiliation of Dr. Xiu-Feng Li. The order of the affiliations "1Department of Pathology, Wei Fang People's Hospital, Weifang 261041, China; 2Shandong University School of Medicine of China, Jinan 250012, China" should be changed to "1School of Medicine, Shandong University, Jinan 250012, China; 2Department of Pathology, Wei Fang People's Hospital, Weifang 261041, China.” The affiliation of Dr. Ting-Guo Zhang should be accordingly changed from "2Shandong University School of Medicine of China, Jinan 250012, China; 3Department of Pathology, Qilu Hospital, Shandong University, Jinan 250012, China" to "1School of Medicine, Shandong University, Jinan 250012, China; 3Department of Pathology, Qilu Hospital, Shandong University, Jinan 250012, China." The affiliation of Dr. YunXiang Zhang should be changed from "1Department of Pathology, Wei Fang People's Hospital, Weifang 261041, China" to "2Department of Pathology, Wei Fang People's Hospital, Weifang 261041, China.”

The authors regret the error and all the inconveniences caused.

Open Access Statement: This is an Open Access article distributed in accordance with the Creative Commons AttributionNonCommercial-NoDerivs 4.0 International License (CC BY-NC-ND 4.0), which permits the non-commercial replication and distribution of the article with the strict proviso that no changes or edits are made and the original work is properly cited (including links to both the formal publication through the relevant DOI and the license). See: https://creativecommons.org/licenses/by-nc-nd/4.0/.

\section{References}

1. Li XF, Zhang TG, Zhang YX. Correlation among VEGFR3 gene promoter methylation, protein overexpression, and clinical pathology in early gastric cancer. Transl Cancer Res 2020;9:3499-506.

Cite this article as: Li XF, Zhang TG, Zhang YX. Erratum to correlation among VEGFR3 gene promoter methylation, protein overexpression, and clinical pathology in early gastric cancer.. Transl Cancer Res 2020;9(10):6624. doi: 10.21037/tcr2020-006 